\title{
Erratum: Green fluorescent protein-based monitoring of endoplasmic reticulum redox poise
}

\section{Christian Appenzeller-Herzog* and Julia Birk}

Division of Molecular and Systems Toxicology, Department of Pharmaceutical Sciences, University of Basel, Basel, Switzerland

*Correspondence: christian.appenzeller@unibas.ch

\section{Edited by:}

Kezhong Zhang, Wayne State University, USA

Keywords: endoplasmic reticulum, endoplasmic reticulum stress, glutathione, green fluorescent protein, hydrogen peroxide, unfolded protein response

\section{A commentary on}

Green fluorescent protein-based monitoring of endoplasmic reticulum redox poise by Birk, J., Ramming, T., Odermatt, A., and Appenzeller-Herzog, C. (2013). Front. Genet. 4:108. doi: 10.3389/ fgene.2013.00108

An error has been identified in the equation to calculate roGFP oxidation (OxD) after our article was published in Frontiers in Genetics. The current equation wrongly features the ratio of ox/red average fluorescence emissions at $390 \mathrm{~nm}$ excitation in the denominator. This should be the ox/red ratio of average fluorescence emissions at $465 \mathrm{~nm}$. Accordingly, the correct equation should read:

$$
\mathrm{OxD}_{\text {roGFP }}=\frac{R-R_{\text {red }}}{\frac{I_{465 \mathrm{~nm} \text { Ox }}}{I_{465 \mathrm{~nm}} \mathrm{red}}\left(R_{\mathrm{ox}}-R\right)+\left(R-R_{\text {red }}\right)}
$$

Received: 02 October 2013; accepted: 08 November 2013; published online: 26 November 2013.
Citation: Appenzeller-Herzog C and Birk J (2013) Erratum: Green fluorescent protein-based monitoring of endoplasmic reticulum redox poise. Front. Genet. 4:255. doi: 10.3389/fgene.2013.00255

This article was submitted to Genomic Endocrinology, a section of the journal Frontiers in Genetics.

Copyright () 2013 Appenzeller-Herzog and Birk. This is an open-access article distributed under the terms of the Creative Commons Attribution License (CC BY). The use, distribution or reproduction in other forums is permitted, provided the original author(s) or licensor are credited and that the original publication in this journal is cited, in accordance with accepted academic practice. No use, distribution or reproduction is permitted which does not comply with these terms. 